\title{
NMDA- and non-NMDA-Receptor Components of Excitatory Synaptic Potentials Recorded from Cells in Layer V of Rat Visual Cortex
}

\author{
Kenneth A. Jones and Robert W. Baughman \\ Department of Neurobiology, Harvard Medical School, Boston, Massachusetts 02115
}

The pharmacological properties of excitatory synapses on pyramidal cells in layer $V$ of rat visual cortex were investigated by recording EPSPs intracellularly in tissue slices. The EPSPs were evoked by electrically stimulating cells in layer II/III or axons in white matter. All of the layer V neurons were pyramidal in nature as determined by injections of Lucifer yellow or by electrophysiological criteria. Application of the broadly acting antagonists kynurenic acid and $\gamma$-D-glutamylglycine reversibly antagonized the EPSPs from both presynaptic sources in a dose-dependent manner: 1 and $5 \mathrm{~mm}$ kynurenic acid produced 63 and $79 \%$ reductions, respectively, of control responses. The specific NMDA antagonist APV $(50 \mu \mathrm{M})$ caused a small reduction in peak amplitude and a more significant reduction in the duration of the falling phase of EPSPs. When slices were bathed in $\mathrm{Mg}^{2+}$-free medium, the amplitude of the EPSP increased substantially. Under these conditions APV reduced the size of the EPSP to that observed with APV in the presence of $1 \mathrm{mM} \mathrm{Mg}^{2+}$. The voltage sensitivities of the APV-sensitive and APV-insensitive components of the layer II/III-evoked EPSPs were examined. The APV-insensitive component was not voltage dependent and had an extrapolated reversal potential of $-10 \mathrm{mV}$. In contrast, the APV-sensitive component showed an NMDA-like voltage dependency; it was greatest at the most positive potentials tested $(-45 \mathrm{mV})$ and nearly absent at membrane potentials below rest. At potentials near threshold, the APV-sensitive component contributed approximately half of the total response. Although the time to peak and decay were longer for the APV-sensitive component, the latency was the same as that of the APV-insensitive component. These results provlde evidence that the layer II/III to V pathway, which comprises a major interlaminar circuit in cortex, is mediated directly through NMDA as well as non-NMDA receptors located on the layer $V$ cells. This finding has implications for the role of this circuit in cortical visual plasticity.

Excitatory amino acids, such as glutamate, are prominent neurotransmitter candidates in a variety of cell types in visual pathways, including photoreceptors and bipolar cells (Bloomfield

\footnotetext{
Received Dec. 14, 1987; revised Feb. 2, 1988; accepted Feb. 8, 1988.

We wish to thank J. Huettner, M. Olivo, and A. Khan for their comments on the manuscript, and J. Gagliardi for photographic assistance. We also thank Astra Pharmaceutical Company for their generous donation of QX-314. This work was supported by an NIH National Research Service Award EY05810 (K.A.J.) and NIH Grant EY03502 (R.W.B.).

Correspondence should be addressed to Kenneth A. Jones, Harvard Medical School, Department of Neurobiology, 220 Longwood Avenue, Boston, MA 02115. Copyright (C) 1988 Society for Neuroscience $0270-6474 / 88 / 093522-13 \$ 02.00 / 0$
}

and Dowling, 1985; Miller and Slaughter, 1986), ganglion cells (Crunelli et al., 1987) in the retina, and geniculate relay cells in the thalamus (Tsumoto et al., 1986). In cortex, the acidic amino acids glutamate and aspartate, based on several lines of evidence, have been proposed as neurotransmitters for excitatory synapses. For example, these substances and their analogs excite cortical neurons (Hayashi, 1954; Curtis and Watkins, 1963; Krnjevic and Phillis, 1963), pyramidal neurons selectively accumulate and transport ${ }^{3} \mathrm{H}-\mathrm{D}-\mathrm{aspartate}$ (Baughman and Gilbert, 1981; Matute and Streit, 1985), and both glutamate and aspartate are released with depolarization in a calcium-dependent manner (Baughman and Gilbert, 1981).

A partial, but still incomplete, battery of receptor agonists and antagonists has led to the hypothesis that there are at least 3 functional types of membrane receptors for glutamate. These have been called kainate, quisqualate, and $N$-methyl-D-aspartate (NMDA) receptors on the basis of agonists that appear to activate specifically the 3 receptor types (Watkins and Evans, 1981). In many preparations, however, since it has not been possible to distinguish electrophysiological responses to kainate from those to quisqualate using currently available antagonists, these 2 receptor subtypes have been collectively called nonNMDA receptors (Mayer and Westbrook, 1987). Although present on almost all neurons responsive to glutamate, the NMDA and non-NMDA receptors contribute unequally to the production of synaptic potentials, at least in well-characterized preparations such as hippocampus and spinal cord. In particular, non-NMDA receptors appear to mediate primarily conventional, fast EPSPs, while NMDA receptors play a role in generating slow EPSPs (MacDermott and Dale, 1987) and in synaptic modulation (Collingridge and Bliss, 1987).

Studies in neocortex suggest that NMDA receptors are involved in generating bursting behavior and epileptiform activity (Baldino et al., 1986; Avoli and Oliver, 1987). In some cases, NMDA receptors appear to be coactivated with non-NMDA receptors at excitatory synapses (Mayer and Westbrook, 1987), but there is evidence that these receptor subtypes are segregated at other synapses (Thomson, 1986; Dale and Grillner, 1986). A recent study of synaptic responses recorded from dissociated visual cortical neurons found that an NMDA component could be observed, but only in the absence of $\mathrm{Mg}^{2+}$ (Huettner and Baughman, 1988). These studies support the view that a large proportion of cortical EPSPs are mediated by receptors for excitatory amino acids; however, the precise functional role of the different receptor subtypes at identified synapses in vivo is unknown.

Determining the relative contributions of NMDA and nonNMDA receptors in generating synaptic potentials is important 


\begin{tabular}{|c|c|c|c|c|c|}
\hline Property & $\begin{array}{l}E_{m} \\
(\mathrm{mV})\end{array}$ & $\begin{array}{l}R_{\mathrm{in}}{ }^{a} \\
(\mathrm{M} \Omega)\end{array}$ & $\begin{array}{l}\text { Spike height } \\
(\mathrm{mV})\end{array}$ & $\begin{array}{l}\text { Spike threshold }{ }^{b} \\
(\mathrm{mV})\end{array}$ & $\begin{array}{l}\text { Spike width }{ }^{c} \\
\text { (msec) }\end{array}$ \\
\hline \multicolumn{6}{|c|}{ Non-dye-filled cells } \\
\hline Mean $\pm \mathrm{SD}$ & $68.0 \pm 4.9$ & $50.6 \pm 18.9$ & $91.5 \pm 11.6$ & $27.6 \pm 6.4$ & $1.8 \pm 0.5$ \\
\hline Range & $60-75$ & $30-90$ & $64-105$ & $14-36$ & $1.3-3.2$ \\
\hline$n$ & 24 & 17 & 15 & 16 & 13 \\
\hline \multicolumn{6}{|c|}{ Lucifer yellow dye-filled cells } \\
\hline Mean $\pm \mathrm{SD}$ & $58.6 \pm 7.4$ & $73.3 \pm 20.8$ & $75.8 \pm 14.6$ & $21.7 \pm 2.9$ & $2.4 \pm 0.5$ \\
\hline Range & $55-70$ & $50-90$ & $60-95$ & $20-25$ & $2.0-3.0$ \\
\hline$n$ & 5 & 3 & 5 & 3 & 5 \\
\hline
\end{tabular}

for understanding visual function. Recent evidence shows that normal patterns of cortical ocular dominance plasticity in kittens (Kleinschmidt et al., 1987) and tectal afferent segregation in tadpoles (Cline et al., 1987) can be disrupted by NMDA receptor blockade. Furthermore, in kitten cortex NMDA receptors contribute more robustly to cortical responses to light during the critical period than in older animals (Tsumoto et al., 1987).

In the present study, in a slice preparation of rat visual cortex, we analyzed the pharmacological properties of excitatory input to pyramidal cells in layer $\mathrm{V}$. Two sources of presynaptic input were studied: (1) the prominent projection from layer II/III to layer $\mathrm{V}$ and (2) inputs from white matter. The results suggest that for both inputs the EPSPs are mediated by NMDA as well as non-NMDA receptors and that at potentials near threshold NMDA receptors contribute as much as non-NMDA receptors to EPSP formation.

\section{Materials and Methods}

Slices were prepared from 22- to 40-d-old Long-Evans rats that had been anesthetized with ketamine $(170 \mathrm{mg} / \mathrm{kg}$, i.m.). This anesthetic was used because of the protection it provides against excitotoxicity (Olney et al., 1986) and because its action is reversible (Thomson et al., 1985). A block of tissue consisting of primary visual cortex (Zilles, 1985) was removed from the brain and coronal sections, $400 \mu \mathrm{m}$ thick, were cut on a Vibratome. Slices were immediately transferred to a holding chamber, where they were preincubated at $20-22^{\circ} \mathrm{C}$ for at least $1 \mathrm{hr}$ under continuously flowing medium containing (in $\mathrm{mM}$ ): $\mathrm{NaCl}, 125 ; \mathrm{KCl}, 5$; $\mathrm{CaCl}_{2}, 3 ; \mathrm{MgSO}_{4}, 1.5 ; \mathrm{NaHCO}_{3}, 26 ; \mathrm{NaH}_{2} \mathrm{PO}_{4}, 1 ;$ glucose, $20 ; 95 \% \mathrm{O}_{2}$ : $5 \% \mathrm{CO}_{2}$. Single slices were transferred to a submersion-type recording chamber through which warmed $\left(32-33^{\circ} \mathrm{C}\right)$ medium flowed at a rate of $5 \mathrm{ml} / \mathrm{min}$. This medium was identical to the above solution with exceptions noted in the text where $\mathrm{MgSO}_{4}$ was omitted. Medium with $\mathrm{MgSO}_{4}$ omitted will be referred to as " $\mathrm{Mg}^{2+}$-free," although no attempt was made to determine the actual concentration of $\mathrm{Mg}^{2+}$ present. Kynurenic acid, glutamic acid diethylester (both from Sigma), D,L-2-amino5-phosphonovaleric acid (APV) and $\gamma$-D-glutamylglycine (both from Cambridge Research Biochemicals) were added directly to the recording solution. Control and test solutions were completely exchanged within the recording chamber within a $1.5 \mathrm{~min}$ period after activating a valve on the inlet line.

Cells in layer $\mathrm{V}$ were impaled with microelectrodes, and electrical signals were recorded with a high-impedance amplifier (WPI M4-A) equipped with a bridge circuit. Microelectrodes had resistances of 50$80 \mathrm{M} \Omega$ when filled with $2.5 \mathrm{M}$ potassium acetate. For intracellular marking, some of these microclectrodes were filled instcad with a solution of $3 \%$ Lucifer yellow (Stewart, 1978) and $100 \mathrm{~mm}$ lithium acetate. Some electrodes contained the quaternary lidocaine derivative QX-314 (50$100 \mathrm{~mm}$; Astra Pharmaceuticals) dissolved in $2.5 \mathrm{M}$ potassium acetate. This sodium channel blocker (Frazier et al., 1970; Strichartz, 1973) was useful for blocking action potentials in experiments that tested the voltage sensitivity of EPSPs, particularly at potentials near threshold. Bipolar stimulating electrodes were made by twisting together 2 strands of $50 \mu \mathrm{m}$ diameter tungsten wire insulated except at their cut ends. Square pulses $0.2 \mathrm{msec}$ in duration were applied to the slice at low frequencies $(0.1-0.5 \mathrm{~Hz})$ to elicit synaptic responses. Data were stored on video tape using a 16 bit digital instrumentation recorder (Medical Systems, Inc.). The averaging and subtracting of records was performed off-line with a digital data acquisition system (Indec Systems-C Lab).

Each slice containing a dye-filled cell was fixed overnight in a $4 \%$ solution of formaldehyde in $0.10 \mathrm{M}$ sodium phosphatc buffer ( $\mathrm{pH} 7.0$ ), dehydrated in an ascending ethanol series, and cleared with methylsalicylate. Neurons were observed at low power to determine their dendritic morphology and laminar position and at high power to determine the laminar extent of their axonal branches. A computer-aided tracing system (Capowsky and Sedivec, 1981) was used for 3-dimensional reconstruction of one of the Lucifer yellow-filled cells.

\section{Results}

Electrophysiological and morphological properties of neurons Intracellular recordings were made from neurons impaled in the upper half of layer $\mathrm{V}$ of primary visual cortex. Impalement of healthy neurons was marked by a $30-50 \mathrm{mV}$ drop in potential and a barrage of action potentials that subsided as the membrane potential hyperpolarized further and stabilized during a period of 1-3 min. The physiological and pharmacological properties of 37 of these cells are described. All cells in the present study had resting potentials between -55 and $-75 \mathrm{mV}$ and overshooting action potentials (Table 1).

In an attempt to determine which cell types were bcing impaled with our microelectrodes, a sample of neurons, whose pharmacological and physiological properties were studied, was intracellularly stained with Lucifer yellow. Five neurons were successfully injected with Lucifer yellow, and one of these is shown in Figure 1. All had morphological features typical of pyramidal cells that are found in layer $\mathrm{V}$ : pyramidal-shaped somata situated in the upper hall of layer $\mathrm{V}$, basal dendrites that extended deep into layer $\mathrm{V}$, and a prominent apical dendrite that arborized extensively in layer I. A single axon projected into the white matter except in 2 cases, where the axon was severed by the plane of section at the level of layer VI. The limited thickness of the slice prevented a complete reconstruction of axon collaterals (see Fig. 1); however, for 4 neurons axon collaterals could be traced to what appeared to be terminations in layer II/III. Boutonlike swellings occurred along collaterals that entered layer II/III and along collaterals that ramified for short distances in layer V. Other collaterals entered lower layer 
1

II/III
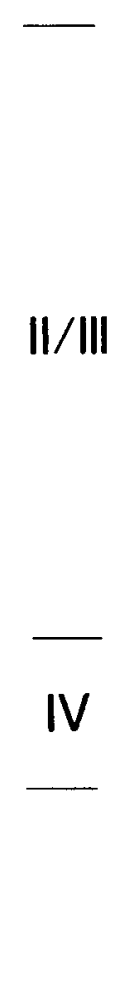

V

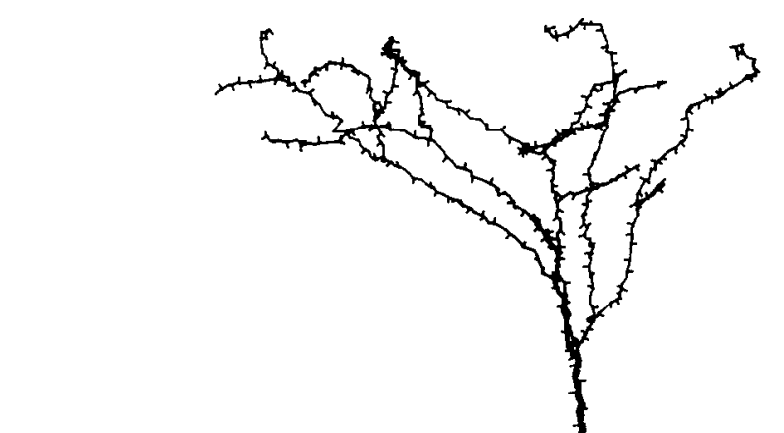



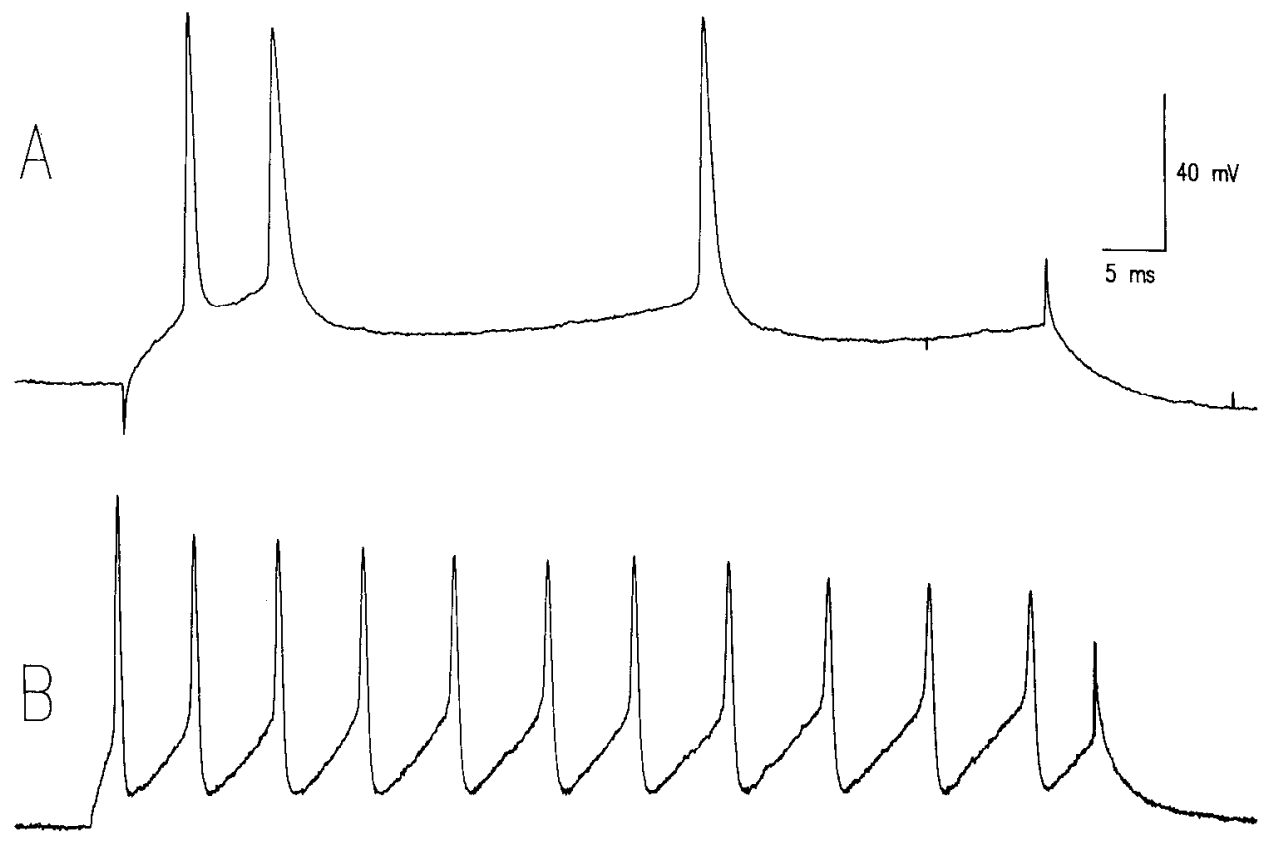

Figure 2. Action potential characteristics of layer $\mathrm{V}$ cells. $A$, Response of the pyramidal cell shown in Figure 1 to injection of a $1.5 \mathrm{nA}$ depolarizing current pulse. Note the increased interval between the second and third spikes compared to the first and second. Resting potential, $-70 \mathrm{mV} . B$, Response of an unidentified, fast-spiking neuron to injection of a $1.8 \mathrm{nA}$ current pulse. Resting potential, $-68 \mathrm{mV}$.

$\mathrm{V}$ and layer VI, but many of these left the plane of section before terminating.

With the Lucifer yellow-filled electrodes it proved difficult to obtain long-term, stable electrical recordings necessary for the pharmacological work; therefore, morphological data were not obtained for most neurons. The action potentials of the nondye-filled neurons, however, provided additional support that they were pyramidal cells. For example, action potentials of non-dye-filled neurons and Lucifer yellow-filled pyramidal cells had similar ranges of spike widths (lable 1), although the mean width for the Lucifer yellow-filled cells was slightly longer, possibly reflecting an effect of the $\mathrm{Li}^{+}$present in the Lucifer ycllow pipets (Mayer et al., 1984). Both cell groups also displayed an adaptation of spike frequency when given prolonged depolarizing current pulses (Fig. $2 A$ ). Action potentials with these characteristics are typical of cells showing pyramidal morphology in guinea pig cerebral cortex (McCormick et al., 1985). In contrast, in that preparation aspiny stellate cells, which are likely to be GABAergic, generated action potentials that had significantly shorter widths and lacked frequency adaptation. Pyramidal cells dissociated from the visual cortex of neonatal rats and grown in culture also have significantly broader action potentials than GABAergic neurons grown under the same conditions (Huettner and Baughman, 1988). Rarely, we recorded for a few minutes from cells whose action potentials were brief $(<1.0$ msec duration at base) and nonadapting (Fig. $2 B$ ). EPSPs were also recorded from these cells, but they are not included in the present study.

EPSPs could be elicited in the cells recorded in layer $\mathrm{V}$ by electrically stimulating white matter or any of the layers in gray matter, except for layer I. We focused on analyzing EPSPs that could be elicited by stimulating either the upper half of layer II/III or white matter, in each case within the same cortical column as the recording electrode. Low-intensity stimuli $(<4$ V) applicd to either source elicited EPSPs graded in proportion to stimulus voltage. These EPSPs had latencies ranging between 2.2 and $3.0 \mathrm{msec}$ and followed stimulus pulses up to $150 \mathrm{~Hz}$, and they were therefore presumed to be monosynaptic. Occa- sionally low-threshold fibers were encountered in the white matter that, when stimulated, elicited polysynaptic EPSPs with longer latencies (3.0-4.2 msec). These EPSPs proved to be unstable during long periods of recording and were not included in this study. Although some layer $V$ cells have axon collaterals in layer II/III (Fig. 1), antidromic potentials were never observed when stimulating this layer, even at high stimulus intensities. For approximately one-third of the neurons, however, stimulation

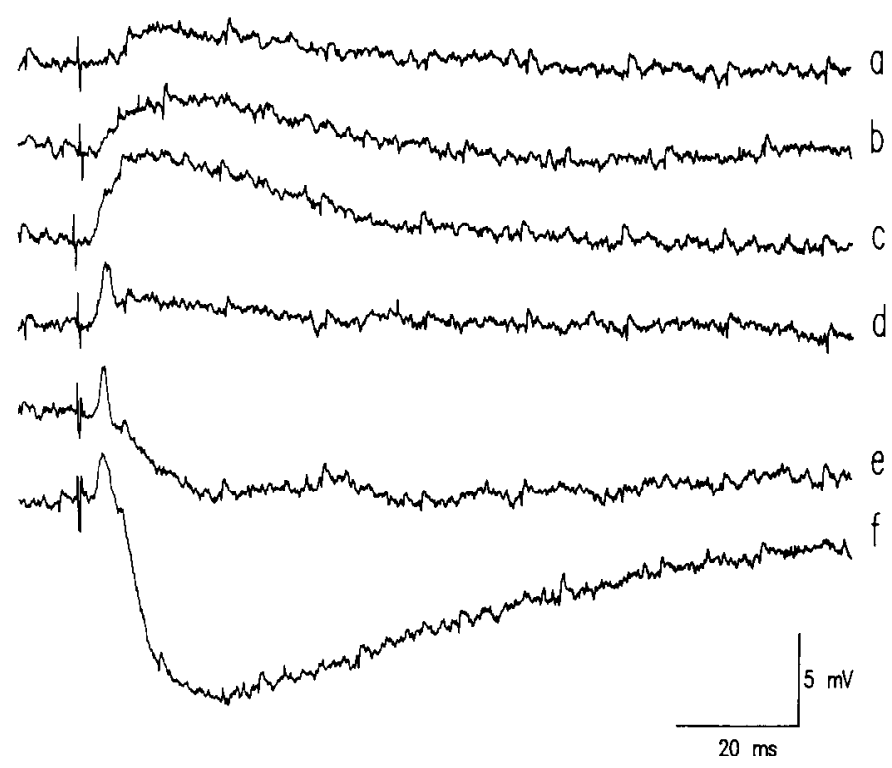

Figure 3. Development of inhibitory postsynaptic potential with increasing stimulus intensity going from trace $a$ to trace $f$. Trace $a$ shows an EPSP resulting from a threshold stimulus (marked by artifact), applied to the upper half of layer II/III. As the stimulus voltage is increased slightly, the EPSP grows, reaching a maximum amplitude in trace $c$. In successive traces $(d-f)$, the EPSP is truncated by summating IPSPs that grow in magnitude as the stimulus voltage is increased further. For all traccs the cell was depolarized from rest to $-58 \mathrm{mV}$ by constant-current injection. 
A Control

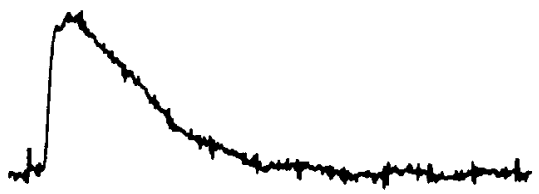

B Control

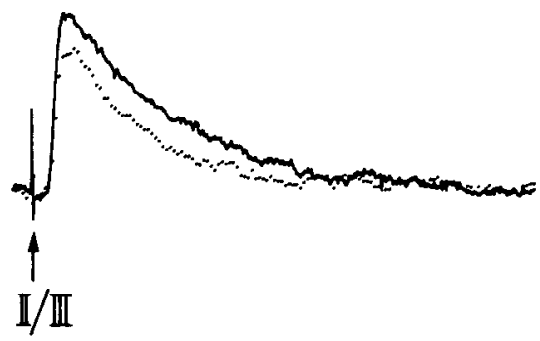

Kyn $5 \mathrm{mM}$

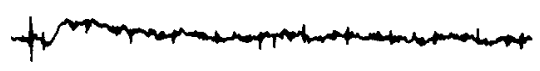

APV 50 uM

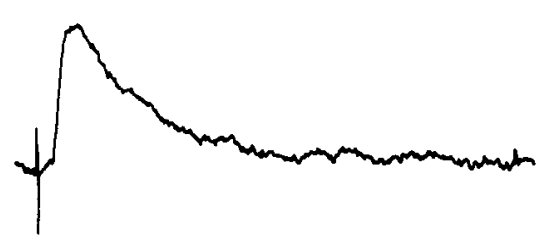

Wosh

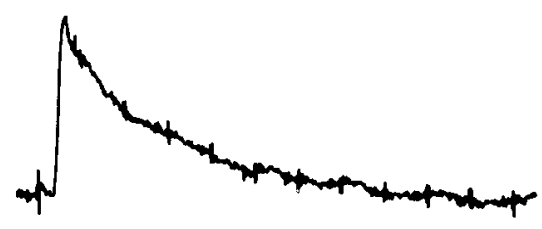

Wosh

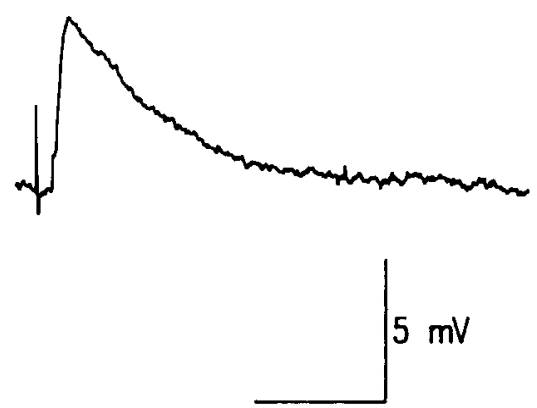

$25 \mathrm{~ms}$

Figure 4. Effect of kynurenic acid and APV on synaptic responses recorded from layer V cells following electrical stimulation of layer II/III. A, Center trace was recorded after a $10 \mathrm{~min}$ application of $5 \mathrm{~mm}$ kynurenate; right trace was taken after a 17 min wash with control medium. Resting potential, $-73 \mathrm{mV} . B$, Response of a different neuron after 8 min with $50 \mu \mathrm{M}$ APV (middle and dotted traces), and after a $14 \mathrm{~min}$ wash. Resting potential, $-72 \mathrm{mV}$.

of white matter, at an intensity just above threshold for EPSP generation, elicited an antidromic action potential.

Frequently, beyond a certain stimulus intensity, EPSPs failed to grow in magnitude due to the development of a powerful hyperpolarization that began before the peak of the underlying EPSP (Fig. 3). This inhibitory component was usually reversed (depolarizing) at rest and was completely and reversibly abolished by bath application of the GABA receptor blocker bicuculline at $10 \mu \mathrm{M}$ (data not shown). This inhibitory synaptic component of the PSP masked an APV-sensitive component, especially under conditions when the cell was depolarized with current to -60 to $-50 \mathrm{mV}$. Attempts to block IPSPs with bicuculline or picrotoxin resulted in the production of polysynaptic activity and depolarization shifts; therefore, especially for the study of APV-sensitive EPSPs, we intentionally used stimulus intensities that were below threshold for IPSPs.

\section{Pharmacology of synaptic responses}

The broadly acting excitatory amino acid antagonist kynurenic acid (Perkins and Stone, 1982; Ganong et al., 1983) reversibly antagonized EPSPs elicited by stimulating either layer II/III (Fig. 4A) or white matter (Fig. 5A). At a bath concentration of $1 \mathrm{mM}$, kynurenic acid reduced the amplitude of EPSPs to an average of approximately $30 \%$ of the control response; $5 \mathrm{~mm}$ kynurenic acid produced a more powerful block (Table 2), although in most cases even this was incomplete. There appeared to be no difference in the sensitivity to kynurenic acid of EPSPs evoked by either layer II/III or white matter. The small depolarizing response that remained after application of $5 \mathrm{~mm} \mathrm{kyn}-$ urenic acid was totally abolished in the presence of $2-5 \mathrm{mM}$
$\mathrm{Co}^{2+}$ (data not shown). Another broadly acting antagonist, $\gamma$-D-glutamylglycine (Davies and Watkins, 1981), at $1 \mathrm{mM}(n=$ 3) was slightly less effective in blocking EPSPs, reducing them to an average of $49 \%$ of the control amplitude. Glutamic acid diethylester, which in the spinal cord is reported to be a specific blocker of quisqualate depolarizations (Davies and Watkins, 1979; McLennan and Lodge, 1979), was completely without effect at $1 \mathrm{~mm}(n=3)$.

In dissociated culture EPSPs recorded from corticocollicular and other visual cortical neurons are usually completely blocked by $1 \mathrm{~mm}$ kynurenic acid (Huettner and Baughman, 1988). Two possible reasons why kynurenic acid at even higher concentrations did not usually produce a complete block of EPSPs recorded from the tissue slices are (1) there are present in the slice other presynaptic sources of input that are not sensitive to glutamate receptor blockade, and (2) all glutamate receptors in the slice do not have equal access to kynurenic acid delivered to the bath. We tested for the second possibility by comparing the kynurenate sensitivity of synaptically evoked depolarizations to that of glutamate-evoked depolarizations produced by brief electrophoretic pulses delivered to a pipet filled with $500 \mathrm{~mm}$ glutamate. The pipet tip was advanced into the slice to within $75 \mu \mathrm{m}$ of the tip of the recording electrode and the magnitude of the current delivering the glutamate was adjusted to elicit a depolarization that was equal in amplitude to the EPSP evoked by layer II/III stimulation (Fig. $6 A$ ). The responses to glutamate were uncontaminated by synaptic potentials since under these conditions glutamate depolarizations were unaffected by a concentration of tetrodotoxin $(1 \mathrm{~mm})$ that blocked all responses to electrical stimulation. Figure $6 B$ illustrates the time course of 
A

\section{Control}

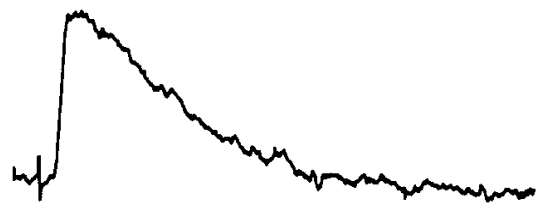

B Control

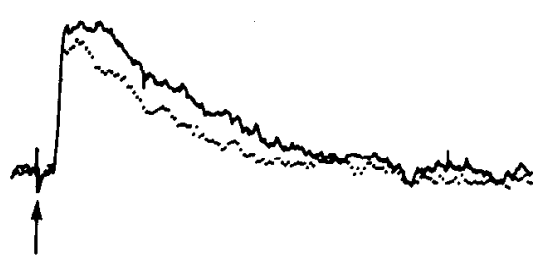

W.M.
Kyn $5 \mathrm{mM}$

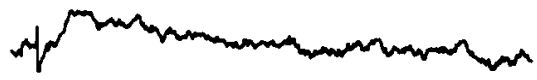

APV 50 uM

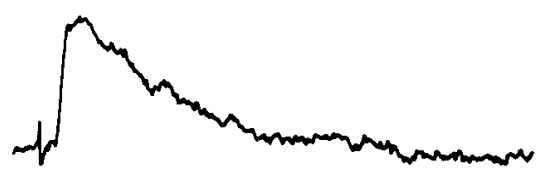

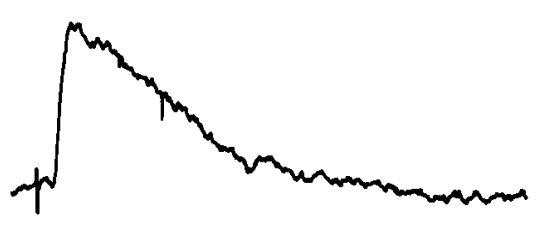

Wosh

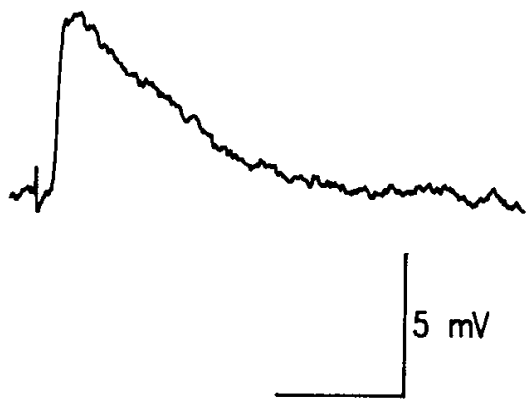

$25 \mathrm{~ms}$

Figure 5. Effect of kynurenate and APV on synaptic responses to stimulation of white matter. $A$, Center trace recorded after 10 min of 5 mm kynurenate; last trace taken after an 11 min wash in control medium. $B$, Responses after 10 min with APV (middle and dotted traces), and after a $9 \mathrm{~min}$ wash. $A$ and $B$ are from the same cell. Resting potential, $-64 \mathrm{mV}$.

the block of synaptic and glutamate-induced depolarizations during a 9 min bath application of $5 \mathrm{~mm}$ kynurenic acid and an $18 \mathrm{~min}$ wash. The amplitudes of both synaptic and glutamateinduced depolarizations fell during the first $5 \mathrm{~min}$ and then remained unchanged until the wash. The results of 4 such experiments confirmed that the response to synaptic input was blocked as effectively as the response to glutamate (Table 2). Thus, the parallel but incomplete antagonism of both the EPSP and glutamate response by kynurenate suggests that, in the slice, some glutamate receptors are relatively inaccessible to this antagonist. The low potency of bath-applied kynurenate may reflect diffusion gradients of glutamate and kynurenate created by the tonic release of glutamate within the slice and, as suggested by Evans and colleagues (1987), by the cellular uptake of kynurenic acid.

\section{An APV-sensitive synaptic component}

The NMDA receptor can be distinguished from non-NMDA receptors by its greater sensitivity to blockade by APV (Watkins and Evans, 1981; Davies and Watkins, 1982). Since kynurenate, at the concentrations we used to block synaptic potentials, prevents the activation of all 3 receptor subtypes (Perkins and Stone, 1982; Ganong et al, 1983; Huettner and Baughman, 1986), we applied APV to determine the contribution of NMDA receptors to the generation of EPSPs. APV at $50 \mu \mathrm{M}$ reduced the peaks of short-latency EPSPs to an average of $84 \%$ of the amplitude of the control response (Figs. $4 B, 5 B$; Table 2). This reduction was reversible and similar for EPSPs evoked by either layer II/III or white matter stimulation. The effect of APV varied somewhat from cell to cell. At resting potentials, for 7 out of
20 cells, APV had no effect on EPSP peak amplitude, although the duration of the EPSP was reduced for 4 of these 7 cells. For those cases when the same neuron was exposed to both kynurenate and APV at separate times, kynurenate always produced a more powerful antagonism of the EPSP. In contrast to the short-latency EPSPs, occasional polysynaptic EPSPs evoked by white matter stimulation were blocked completely by $50 \mu \mathrm{M}$ APV.

In addition to being blocked by APV, membrane depolarizations caused by the activation of NMDA receptors can be inhibited by physiological levels of $\mathrm{Mg}^{2+}$ in a voltage-dependent manner (Nowak et al., 1984; Mayer and Westbrook, 1985). At resting potentials most commonly encountered in the slice, ap-

Table 2. Effects of kynurenate and APV on synaptic and glutamateevoked depolarizations of cells in layer $V$

\begin{tabular}{llrl} 
& \multicolumn{2}{l}{ Kynurenate } & \\
\cline { 2 - 3 } Stimulus & $1 \mathrm{mM}$ & $5 \mathrm{~mm}$ & APV, 50 mM \\
\hline White matter & $31 \pm 9(5)$ & $9 \pm 9(3)$ & $84 \pm 4(10)$ \\
Layer II/III & $36 \pm 12(4)$ & $21 \pm 7(6)$ & $84 \pm 5(11)$ \\
Glutamate $^{a}$ & $34 \pm 4(2)$ & $19 \pm 4(3)$ &
\end{tabular}

Lucifer yellow-filled cells

White matter $\quad 36 \pm 10(4)$

$89 \pm 9$

All values are shown as percentages of control EPSP peak amplitude and represent the mean $\pm \mathrm{SE}$ of $(n)$ different cells.

a Glutamate was ejected iontophoretically $(50-100 \mathrm{nA}, 200 \mathrm{msec})$ to elicit depolarizations equal in amplitude to the responses evoked by stimulating layer II/III. 


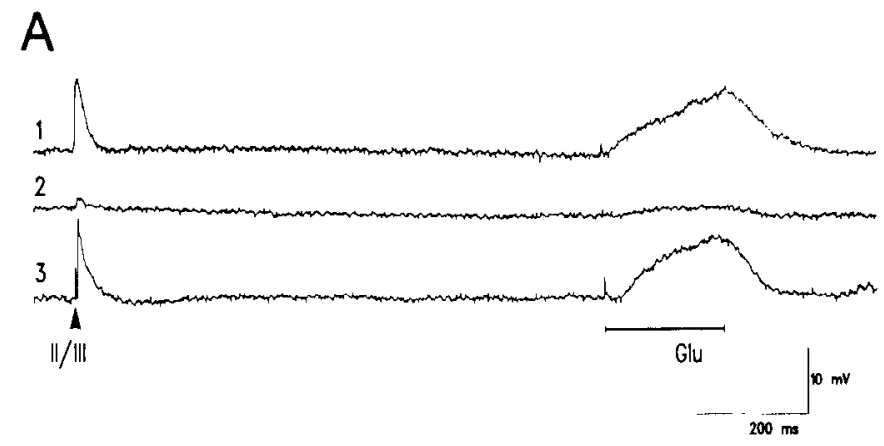

B

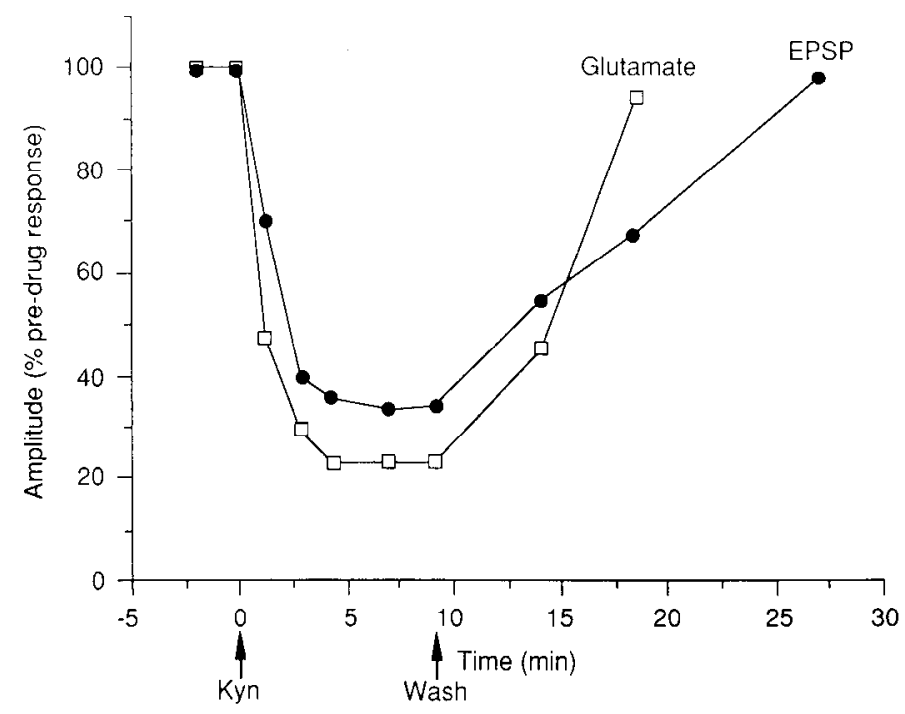

Figure 6. Comparison of effects of $5 \mathrm{~mm}$ kynurenic acid on synaptic potentials and glutamate-evoked depolarizations. $A 1$, Recording of EPSPs elicited by stimulation of II/III (at arrow) followed 1 sec later by a depolarization resulting from iontophoresis of glutamate (duration of application marked by bar). The tip of the pipet containing $500 \mathrm{~mm}$ glutamate, $\mathrm{pH} 7.4$, was positioned approximately $75 \mu \mathrm{m}$ from the recording electrode tip. The current delivering the glutamate was adjusted to $-80 \mathrm{nA}$ to elicit a depolarization that was equal in amplitude to the EPSP. A2, Recording of responses to stimulation of layer II/III and glutamate after $10 \mathrm{~min}$ in the presence of $5 \mathrm{~mm}$ kynurenate and $(A 3)$ following an $11 \mathrm{~min}$ wash in control medium. $B$, Time course of kynurenate antagonism of synaptic and glutamate responses taken from a different cell. Each point represents the average of 3 responses taken at $10 \mathrm{sec}$ intervals. Stimuli were not delivered during the time between points. Methods of iontophoresis same as for $(A)$. Iontophoresis of glutamate caused action potentials after $25 \mathrm{~min}$, and the amplitude of the depolarization could not be accurately measured thereafter.

proximately $-70 \mathrm{mV}$, currents evoked by NMDA receptor activation should be greatly attenuated. To determine if $\mathrm{Mg}^{2+}$ present in the normal recording medium was blocking a portion of the APV-sensitive EPSP evoked by layer II/III or white matter, experiments were performed in reduced $\mathrm{Mg}^{2+}$ in the presence and absence of APV. In $\mathrm{Mg}^{2+}$-free medium (Materials and Methods), the amplitude and time course of EPSPs increased dramatically over those recorded in $1 \mathrm{mM} \mathrm{Mg}^{2+}(n=3$; Fig. 7). The size of the EPSP continued to grow well after the bulk exchange of solutions in the slice chamber had taken place, and usually within $10 \mathrm{~min}$ low-frequency $(<0.1 \mathrm{~Hz})$ stimuli produced large depolarizing shifts. When APV was added to the
Table 3. Time course and latency for $\mathbf{A P V}$-sensitive and $\mathrm{APV}-$ insensitive components

\begin{tabular}{lcll} 
& $\begin{array}{l}\text { Time to } \\
\text { peak } \\
(\mathrm{msec})\end{array}$ & $\begin{array}{l}\text { Time to } \\
\text { half-decay } \\
\text { from peak } \\
(\mathrm{msec})\end{array}$ & $\begin{array}{l}\text { Latency } \\
(\mathrm{msec})\end{array}$ \\
\hline $\begin{array}{l}\text { APV-sensitive } \\
\text { APV-insensitive }\end{array}$ & $19.6 \pm 6.3$ & $51.4 \pm 11.0$ & $2.8 \pm 0.3$ \\
$\begin{array}{l}\text { Ratio of APV-sensitive/ } \\
\text { APV-insensitive }\end{array}$ & $4.7 \pm 1.4$ & $21.6 \pm 8.8$ & $2.6 \pm 0.5$ \\
& $4.2 \pm 0.5$ & $2.5 \pm 0.7$ & $1.1 \pm 0.1$
\end{tabular}

Values are means \pm SD of the digitally averaged responses of the 3 neurons represented in Fig. 10. For all cells the membrane potential was depolarized to between -62 to $-58 \mathrm{mV}$. The APV-sensitive component of the EPSP was derived by digitally subtracting the component remaining in the presence of $50 \mu \mathrm{M}$ APV (APV-insensitive component) from the EPSP recorded in control medium.

$\mathrm{Mg}^{2+}$-free medium, the amplitude of the EPSP dropped back to that observed in solution containing normal levels of $\mathrm{Mg}^{2+}$ plus APV. Therefore, it seems likely that the augmentation of EPSP size in solutions lacking $\mathrm{Mg}^{2+}$ resulted from a direct effect on the NMDA receptor/channel and not from a nonspecific effect of lowered divalent cation activity on membrane excitability, or from the release of $\mathrm{Mg}^{2+}$ block of $\mathrm{Ca}^{2+}$ channels in the presynaptic terminals.

The unmasking of NMDA receptor-mediated excitation by lowered $\mathrm{Mg}^{2+}$ probably causes an augmentation of synaptic excitation throughout the slice. Enhanced polysynaptic activity may have contributed to the large synaptic potentials recorded in lowered $\mathrm{Mg}^{2+}$. To provide a better estimate of the magnitude of the NMDA receptor-mediated component of the EPSP recorded from layer $V$ cells, a series of current-clamp experiments was performed in the presence of $\mathrm{Mg}^{2+}$. These experiments were performed only for the layer II/III-evoked EPSPs because both layer II/III- and white matter-evoked EPSPs had similar sensitivities to APV and because cell types contributing to the white matter-evoked EPSP were unidentifiable.

The voltage dependence of EPSPs generated by stimulating layer II/III was determined for 7 layer $V$ neurons in the presence or absence of APV. For all cells the APV-sensitive component of the EPSP, measured as the difference between peak amplitudes before and during APV application, was greatest at the most depolarized potentials and smallest or unmeasurable at the most hyperpolarized potentials (Fig. 8). Even for those cells that exhibited a relatively large APV-sensitive component there was no tendency for the response to potentiate within the tested frequencies $(0.1-0.5 \mathrm{~Hz})$. In addition to the increase in relative EPSP amplitude with depolarization, there was also an increase in the duration of the response. Upon subtraction of the EPSP recorded in the presence of APV from the total EPSP, it became clear that the time to peak and decay time were 2- to 3-fold greater for the APV-sensitive than for the APV-insensitive component (Fig. 9, Table 3). These differences did not result from differences in latencies of the 2 components. For the 3 neurons from which the latency of the APV-sensitive component was large enough to be measured accurately, there was no measurable difference between this latency and that of the APV-insensitive component (Fig. 9, Table 3).

The observation that the APV-sensitive and APV-insensitive components had quite different time courses means that in order to compare their overall effects on membrane potential it is necessary to take into account changes in both amplitude and 


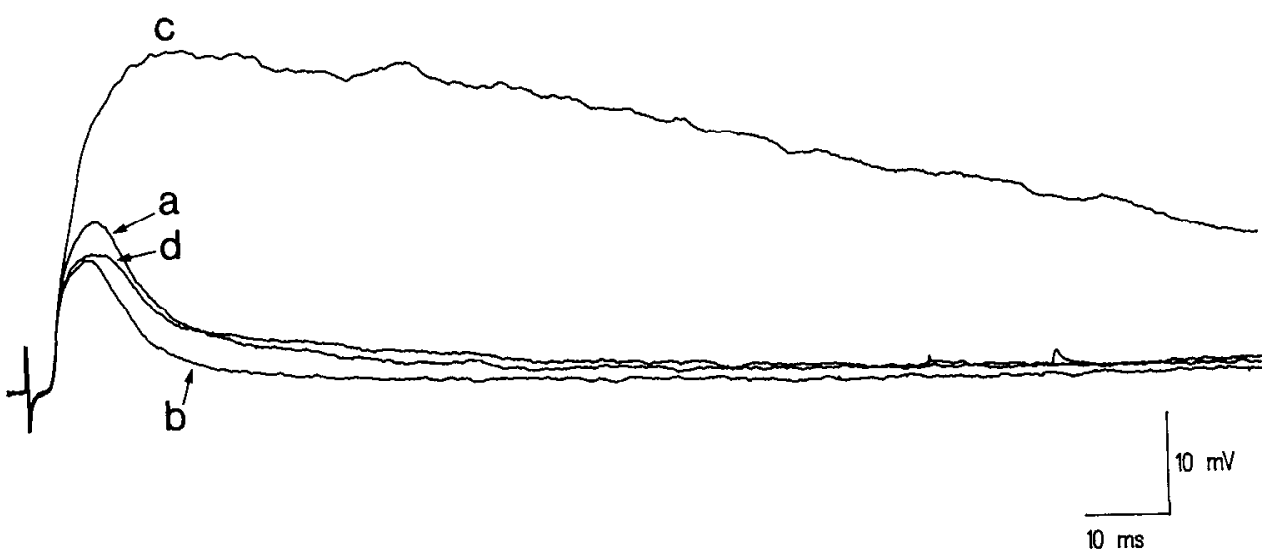

Figure 7. Effect of $\mathrm{Mg}^{2+}$-free medium on EPSPs evoked by stimulating layer II/III. In the presence of $\mathrm{Mg}^{2+}$ (1 $\left.\mathrm{mM}\right)$, $50 \mu \mathrm{M}$ APV (trace $b$ ) produced a modest reduction of the EPSP compared to the control (trace $a$ ). After an $8 \mathrm{~min}$ application of $\mathrm{Mg}^{2+}$-free solution (trace $c$ ), the EPSP became considerably larger. Application of the same $\mathrm{Mg}^{2+}$-free medium with added $50 \mu \mathrm{M}$ APV for $8 \mathrm{~min}$ (trace $d$ ) reduced the size of the EPSP to near that with APV plus normal $\mathrm{Mg}^{2+}$ (trace $b$ ). Resting potential, $-66 \mathrm{mV}$. time course. Therefore, areas were calculated as the amplitude integrated over time for the APV-sensitive and APV-insensitive components. Figure 10 illustrates the effect of the membrane potential on the amplitude time integrals of the APV-sensitive and APV-insensitive components for 3 neurons that demonstrated the full range of responses. The integral of the $\Lambda \mathrm{PV}$ insensitive component of the EPSP became steadily larger with hyperpolarization and the average extrapolated reversal potential for the 3 neurons was $-13 \mathrm{mV}$. This value agrees well with the value for reversal potential obtained by extrapolating EPSP amplitudes $(-9 \mathrm{mV})$ for these same cells. The integral of the APV-sensitive component of the EPSP, in contrast, became steadily larger with depolarization in the tested range of -90 to $-50 \mathrm{mV}$. Close to the resting potential (about $-70 \mathrm{mV}$ ), the magnitude of the APV-sensitive component was smaller than that of the APV-insensitive component. At potentials between rest and threshold for spike generation, however, the size of the APV-sensitive component eventually equalled or surpassed that of the APV-insensitive component.

\section{Discussion}

\section{Morphological and electrophysiological observations on layer} $\checkmark$ cells

The morphological properties of the pyramidal cells in layer $\mathrm{V}$ of rat visual cortex that were labeled with Lucifer yellow are similar to those observed by others using a variety of other staining techniques (Parnavelas et al., 1977, 1983; Schoficld ct al., 1987). These pyramidal neurons have apical dendrites ex-

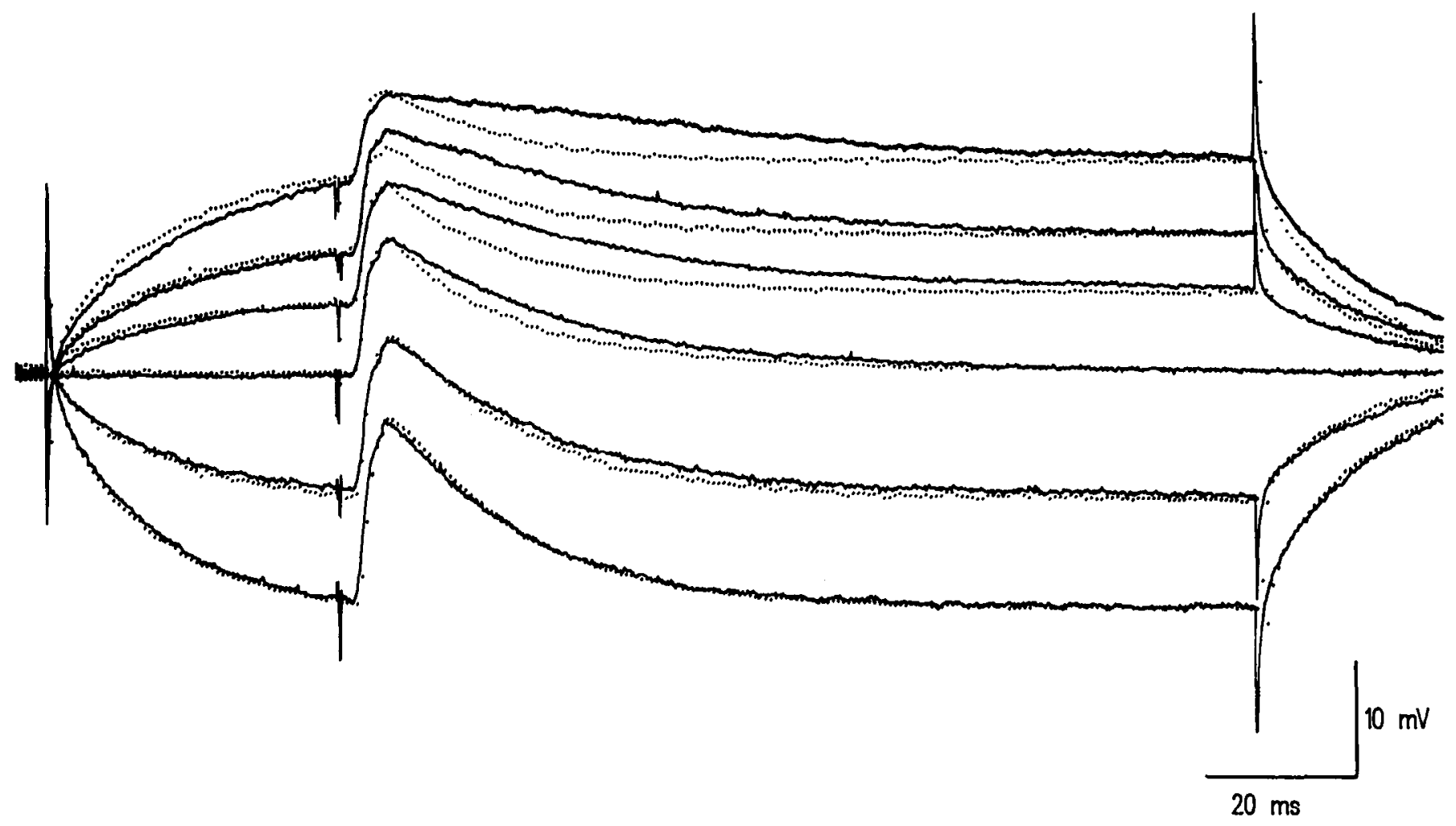

Figure 8. EPSPs evoked by stimulating layer II/III while recording at different membrane potentials. Each trace is an average of 3-5 successive events. Solid traces are recordings in the presence of normal medium. Dotled traces were obtained after 8 min in medium containing $50 \mu \mathrm{M}$ APV. Resting potential, $-68 \mathrm{mV}$. The recording electrode contained $50 \mathrm{~mm}$ QX-314 in $2.5 \mathrm{M}$ potassium acetate. 


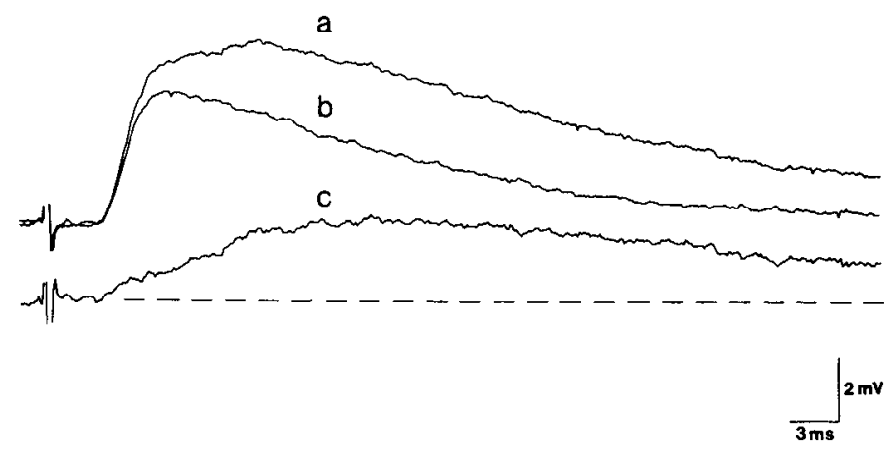

Figure 9. Time course of APV-sensitive and APV-insensitive components of EPSPs elicited by stimulating layer II/III. Upper traces are the control EPSP $(a)$ and the EPSP remaining after an $8 \mathrm{~min}$ application of $50 \mu \mathrm{M}$ APV $(b)$. Each is the average of 4 responses recorded with the cell depolarized to $-62 \mathrm{mV}$. Trace $c$ is the result of a digital subtraction of the 2 upper traces and represents the APV-scnsitive component. The recording electrode contained $50 \mathrm{~mm}$ QX-314 in 2.5 m potassium acetate.

tending into layer I. Schofield and colleagues (1987) have shown that corticotectal cells, as a rule, are of this type, while the apical dendrites of corticocallosal cells in layer $\mathrm{V}$ are frequently short, extending only to layers IV or II/III (Hallman et al., 1988). Their results suggest that the presence of a long apical dendrite may be a marker for corticotectal cells in layer $\mathrm{V}$ and support the interpretation that the Lucifer yellow-filled cells in the present experiment project to superior colliculus.

Based upon the electrophysiological characteristics of all cells in the present study, it seems likely that the non-Lucifer yellowstained neurons also were pyramidal in nature. Approximately one-third of the unstained cells produced antidromic action potentials with stimulation of white matter, indicating that they were projection neurons and thus pyramidal cells. Those that did not may have had their axons severed, or the antidromic spike may not have reached the soma, as has been observed for other rat neocortical neurons (Thomson; 1986). In the guinea pig neocortex, pyramidal neurons and nonpyramidal neurons have strikingly different action potential characteristics (McCormick et al., 1985). The action potentials of cells displaying a pyramidal morphology were broad and showed frequency accommodation, while nonpyramidal, presumably GABAergic, cells had narrow, nonaccommodating spikes. Furthermore, a direct relationship between narrow spike width and inhibitory function was demonstrated for dissociated rat visual cortical neurons grown in culture (Huettner and Baughman, 1988). All neurons tested pharmacologically in the present report had broad action potentials that displayed frequency accommodation. In addition, occasional cells were encountered that produced fast, nonaccommodating action potentials, but these could be held only briefly, suggesting that they were small in size.

\section{Presynaptic sources of excitatory input onto layer V cells}

Ultrastructural studies of rat striate cortex provide evidence that pyramidal cells in layer $\mathrm{V}$ receive synaptic input from a variety of sources, including intracortical axon collaterals and afferents emerging from the subcortical white matter. A principal source of intralaminar axon collaterals is pyramidal cells in layer II/ III (Butler and Jane, 1977). Presynaptic input arising from white matter includes a small input from geniculocortical afferents (Peters et al., 1979). Other sources that are known to terminate in layer $\mathrm{V}$ include axon collaterals from corticocollicular cells

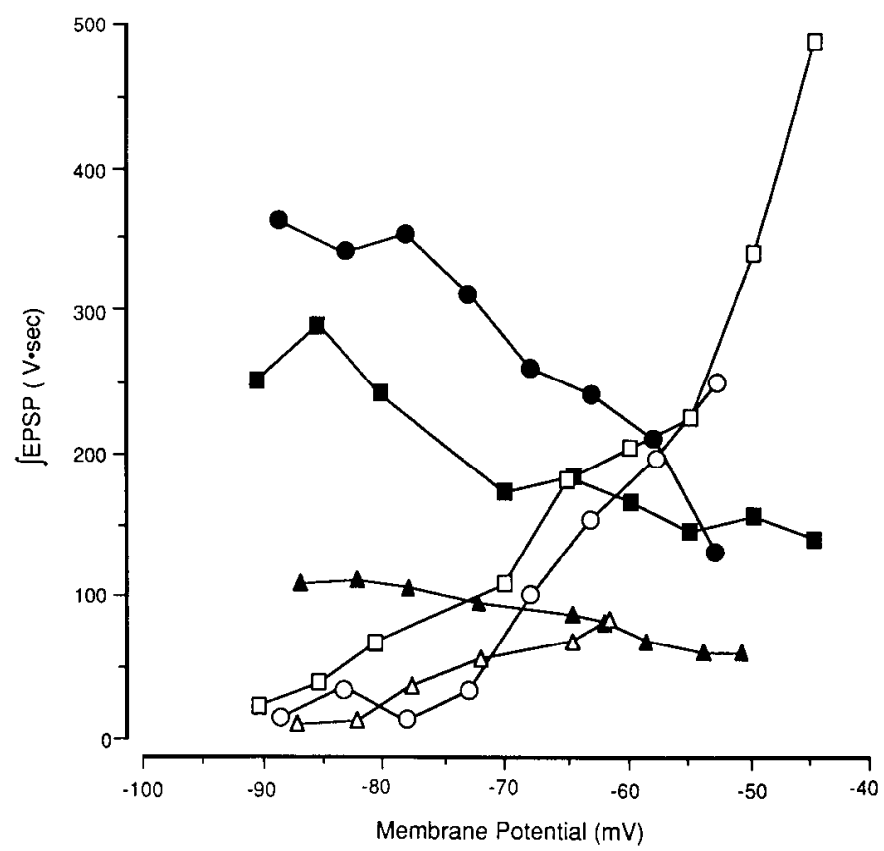

Figure 10. Voltage dependence of APV-sensitive and APV-insensitive components of EPSPs recorded from 3 layer V cells. EPSPs were evoked by stimulating layer II/III. Averages of EPSPs in the presence of $50 \mu \mathrm{M}$ APV (APV-insensitive component) were digitally subtracted from averages of control EPSPs to obtain the APV-sensitive components as per Figures 8 and 9 . Integrals were obtained by reproducing the averaged electrical records on vellum paper, cutting them out, and weighing them. Open symbols show the voltage dependence of the APV-sensitive components of 3 cells, and the respective closed symbols show the voltage dependence of the APV-insensitive components of the same 3 cells. The APV-sensitive component of the cell represented by open triangles could not be measured at potentials more positive than $-62 \mathrm{mV}$ due to an insufficient block of sodium channels by QX-314.

in layer V (Schofield et al., 1987), visual callosal afferents (Cipolloni and Peters, 1979; Cusick and Lund, 1981; Olavarria and Van Sluyters, 1983; Miller and Vogt, 1984), and cholinegic fibers from the basal forebrain (Houser et al., 1985; Eckenstein et al., 1988).

In the present study, EPSPs were produced in layer $\mathrm{V}$ cells by stimulating cells in the upper half of layer II/III, as well as by stimulating a heterogeneous set of fibers that emerge from white matter. We believe that the EPSPs produced by lowintensity stimulation of upper layer II/III resulted from the synchronous firing of a small set of layer II/III pyramidal cells. Other potential sources of presynaptic input from layer II/III are pyramidal cells in layers V and VI. The layer V cells (Fig. 1) have apical dendrites and axon collaterals extending into layer II/III that conceivably could be stimulated antidromically to release transmitter onto other layer $\mathrm{V}$ cells. We feel this did not occur, however, since in no case did stimulation of layer II/III produce antidromic potentials in layer $\mathrm{V}$ cells. Collaterals of layer VI cells project heavily to layer IV but would not be antidromically driven by the stimulating electrode, which was always placed in the upper half of layer II/III.

In contrast to layer II/III, stimulation of white matter can activate a number of presynaptic sources, including geniculate and cortical afferents, as well as axon collaterals of intracortical pyramidal cells through antidromic activation of their efferents. Our rationale for studying synaptic potentials evoked by stimulating white matter was to attempt to drive a heterogeneous 
population of presynaptic inputs and thus to characterize electrophysiologically and pharmacologically the different classes of synaptic receptors present on layer $\mathrm{V}$ pyramidal cells. In fact, the sensitivity of white matter inputs with regard to APV and kynurenic acid was about the same as that of layer II/III. The observation that nearly all EPSPs evoked by whitc mattcr stimulation were blocked by broad-spectrum antagonists of excitatory amino acids suggests that other neurotransmitter receptors play at most a minor role in mediating conventional, fast synaptic excitation in the visual cortex.

\section{Pharmacological properties of excitatory synapses formed on} layer $V$ cells

The present findings demonstrate that the broad-spectrum antagonist kynurenic acid (Perkins and Stone, 1982; Ganong et al., 1983) blocks glutamate and synaptic excitation with equal effectiveness, suggesting that glutamate, or a closely related analog, is the neurotransmitter mediating synaptic excitation in this system. Kynurenic acid has previously been shown to block excitatory transmission between cortical pyramidal cells maintained in culture (Huettner and Baughman, 1986) as well as EPSPs recorded from hippocampal (Ganong ct al., 1983) and spinal cord neurons (Jahr and Jessell, 1985; Jahr and Yoshioka, 1986). Excitatory postsynaptic potentials were antagonized, in addition, by $\gamma$-D-glutamylglycine, which also acts on all 3 receptor subtypes (Collingridge et al., 1983a, b; Crunelli et al., 1983; Huettner and Baughman, 1986; O'Brien and Fischbach, 1986a) but were unaffected by glutamic acid diethylester. Although in some preparations glutamic acid diethylester appears to act preferentially on quisqualate receptors (Davies and Watkins, 1981; Rothman and Samaie, 1985), in others, including visual cortex, glutamic acid diethylester has little or no effect on quisqualate or synaptic depolarizations (Collingridge et al., 1983a, b; Huettner and Baughman, 1986). The characterization of possible non-NMDA receptor subtypes on cortical neurons will require the development of more powerful and selective antagonists.

\section{Contribution of NMDA receptors to synaptic potentials}

Responses mediated by NMDA receptors can be distinguished from those mediated by kainate or quisqualate receptors by their sensitivity to micromolar concentrations of D-APV (Watkins and Evans, 1981; Davies et al., 1982) and by a voltage dependency imposed by the presence of physiological concentrations of $\mathrm{Mg}^{2+}$ (Nowak ct al., 1984; Mayer and Westbrook, 1985). Others have shown that neocortical neurons, including corticocollicular neurons of visual cortex, have receptors for NMDA that can be blocked by APV (Flatman et al., 1986; Huettner and Baughman, 1986; Thompson, 1986). Our results demonstrate an APV-sensitive component of EPSPs recorded in layer $\mathrm{V}$ cells following stimulation of layer II/III or white matter. This component occurs in the presence of physiological concentrations of $\mathrm{Mg}^{2+}$, is greatly enhanced in $\mathrm{Mg}^{2+}$-free medium, and, at least in the case of EPSPs mediated by layer II/III, is voltage dependent. This voltage-dependent property implies that the transmitter released by layer II/III cells acts on NMDA receptors on the impaled layer $\mathrm{V}$ cells and not on interposed neurons in a polysynaptic pathway.

These findings generally agree with previous studies indicating that NMDA receptors contribute to $x$ synaptic responses in layer II/III cells evoked by whitc mattcr stimulation (Thomson, 1986; Artola and Singer, 1987). Thomson (1986) recorded all-or-none
EPSPs from sensorimotor cortex that displayed purely NMDA-like sensitivities to membrane potential and APV, as well as EPSPs that showed only properties of non-NMDA receptors. The nonNMDA EPSPs were unaffected by prolonged application of $\mathrm{Mg}^{2+}$ free medium. In contrast, we did not observe any purely NMDAor non-NMDA-mediated EPSPs, and all EPSPs, including those that were just threshold, strongly potentiated after exposure to $\mathrm{Mg}^{2+}$-free solution. Although at normal resting potentials the NMDA component was small, near action potential threshold it became larger than the non-NMDA component. Thomson recorded from layer II/III pyramidal cells, whereas we recorded from layer $\mathrm{V}$ pyramidal cells, which may account for some of the differences. In Thomson's experiments the purely NMDA EPSPs appeared to be polysynaptic in origin, with latencies of 7-20 msec, which prompted the hypothesis that the NMDA responses were produced by cortical interneurons. In our experiments with stimulation of layer II/III, the NMDA component of the response has the same short latency as the nonNMDA component, which supports the interpretation that both components are driven monosynaptically. We could not reliably resolve unitary EPSPs, and thus we cannot strictly rule out the possibility that the EPSPs scen here were made up of a combination of purely NMDA and purely non-NMDA synapses. For example, in the lamprey spinal cord unitary EPSPs show either NMDA-type, non-NMDA-type, or mixed pharmacologies depending upon the cell pairs that are recorded (Dale and Grillner, 1986).

In tissue culture, the pharmacology of unitary EPSPs has been examined in more detail (Forsythe and Westbrook, 1988; O'Brien and Fischbach, 1986b; Huettner and Baughman, 1988). These studies suggest that each unitary EPSP contains both NMDA and non-NMDA components, although the relative proportion of the 2 components varies considerably. In the absence of $\mathrm{Mg}^{2+}$, EPSPs recorded from neurons from rat visual cortex grown in culture had an NMDA component that ranged from undetectable to equal in magnitude to the non-NMDA component (Huettner and Baughman, 1988). This NMDA component could not be detected in the presence of normal lcvels of $\mathrm{Mg}^{2+}$. Some spinal cord neurons grown in culture exhibit no NMDA component in their EPSPs (Nelson et al., 1986), while others do (Forsythe and Westbrook, 1986; O'Brien and Fischbach, 1986b). In our studies in tissue slices, at resting potentials comparable to those of the neurons grown in culture, nearly all synaptic responses had a detectable NMDA component, even in the presence of $\mathrm{Mg}^{2+}$. One possible explanation for the variability of the NMDA component in the tissue cultures, and the larger NMDA component in the slices, concerns the concentration of extracellular glycine. Glycine at micromolar concentrations has been shown to enhance NMDA responses (Johnson and Ascher, 1987). The glycine concentration in the medium may vary in the tissue cultures, and it may be held at a relatively high level in the extracellular space of $400 \mu \mathrm{m}$-thick tissue slices.

APV-sensitive synapses, in the presence of physiological levels of $\mathrm{Mg}^{2+}$, have been described in cells from a variaty of other CNS regions, including the hippocampus (Dingledine et al., 1986; Hablitz and Langmoen, 1986; Wigstrom et al., 1986), red nucleus (Davies et al., 1986), and spinal cord (O'Brien and Fischbach, 1986b; Forsythe and Westbrook, 1988). In all of these studies, as well as the present one, the APV-sensitive component became apparent only when the postsynaptic cell was depolarized to near threshold. Additionally, at least for slices, it appears to be important to limit $g_{\mathrm{GABA}}$, either by adding picrotoxin or 
bicuculline (Herron et al., 1985; Dingledine et al., 1986; Hablitz and Langmoen, 1986; Artola and Singer, 1987) or by stimulating below the threshold for activation of GABAergic neurons (Thomson, 1986). In the present study, the use of stimulating voltages that did not fire disynaptic, GABAergic IPSPs was critical to the observation of the NMDA component. This relationship between inhibition and NMDA receptor/channel activity may explain the apparent role of decreased inhibition in the development of epileptiform activity in neocortex and hippocampus (Ribak et al., 1982; Sloviter, 1987).

\section{Role of excitatory amino acid receptor subtypes in visual cortical function}

Within the primary visual cortex nearly every type of projection cell has been proposed to use glutamate as a neurotransmitter based upon one or more of the following criteria: their selective uptake and transport of ${ }^{3} \mathrm{H}-\mathrm{D}$-aspartate (Baughman and Gilbert, 1981; Elberger and Looney, 1985); endogenous content of glutamate and aspartate (Karlsen and Fonnum, 1978); aspartatelike (Madl et al., 1987), glutamate-like (Madl et al., 1986), and glutaminase-like (Donoghue et al., 1985) immunoreactivities; and the pharmacology of their synaptic connections (Tsumoto et al., 1986: Huettner and Baughman, 1988). Our results demonstrate that, at least in the layer II/III to $\mathrm{V}$ pathway in rats, NMDA receptors mediate a sizable proportion of the total EPSP, especially at membrane potentials just below threshold. Typical of NMDA responses observed in other systems (Dale and Grillner, 1986; Buchanan et al., 1987), the time course of these potentials is 2-3 times slower than the non-NMDA component. The duration of the NMDA component as well as its selectivity for $\mathrm{Ca}^{2+}$ (MacDermott et al., 1986) may be important for its hypothesized role in plastic changes, such as long-term potentiation (Lynch and Baudry, 1984; Collingridge and Bliss, 1987), and in fact Artola and Singer (1987) have provided evidence that NMDA receptors are involved in generating long-term potentiation in tissuc sliccs of adult rat visual cortex.

One well-known form of plasticity characteristic of the visual cortex of some mammals is the experience-dependent shift of ocular dominance that can be induced during the critical period (Wiesel and Hubel, 1963). It has recently been shown that APV blocks the shift in ocular dominance following monocular deprivation in kittens (Kleinschmidt et al., 1987) and the segregation of tectal afferents in tadpoles (Cline et al., 1987), which suggests that NMDA receptors may play a role in the development of connectivity in visual cortex. In support of this possibility, Tsumoto and his colleagues (1987) have found that the efficacy of NMDA receptors is greater in kittens during the critical period than during the periods before and after.

Although it is difficult to demonstrate the induction of plastic changes in the visual cortex of rats due to the lack of well-defined ocular dominance and orientation columns, other criteria have been used to suggest the existence of a critical period in the normal development of the rat visual cortex. For example, Walk and Walters (1973) have found that rats, with a loss of depth perception induced by dark-rearing, can recover if exposed to a lit environment on postnatal day 30 but not after day 60 . This critical period coincides with that during which other visually dependent modifications of primary visual cortex occur, such as the stimulation of tubulin synthesis (Cronly-Dillon and Perry, 1979) and the asymmetrical enrichment of callosal projections to primary visual cortex of monocularly enucleated rats (Wree et al., 1985). We tested the NMDA component of the layer II/ III to $\mathrm{V}$ pathway in juvenile rats whose visual cortices, while substantially developed in terms of their anatomically and chemically differentiated cell types (Chronwall and Wolf, 1980; Juraska, 1982; McDonald et al., 1982a, b; Olavarria and Van Sluyters, 1985), may have been relatively rich in NMDA receptors. As mentioned above, in cats the contribution of NMDA receptors in generating responses in cortex decreases after the critical period (Tsumoto et al., 1987), and in rats the concentration of glutamate binding sites in visual cortex drops over 10-fold from postnatal day 15 to day 50 (Schliebs et al., 1986). By showing that NMDA receptors play an important role in a major intracortical pathway during this period, the present study provides electrophysiological evidence consistent with the hypothesis that NMDA receptors are involved in the refinement of functional connections during the postnatal development of the visual cortex.

\section{References}

Artola, A., and W. Singer (1987) Long-term potentiation and NMDA receptors in rat visual cortex. Nature 330: 649-652.

Avoli, M., and A. Olivier (1987) Bursting in human epileptogenic neocortex is depressed by an N-methyl-D-aspartate antagonist. Neurosci. Lett. 76: 249-254.

Baldino, F., B. Wolfson, U. Heinemann, and M. J. Gutnick (1986) An N-methyl-D-aspartate (NMDA) receptor antagonist reduces bicuculline-induced depolarization shifts in neocortical explant cultures. Neurosci. Lett. 70: 101-105.

Baughman, R. W., and C. D. Gilbert (1981) Aspartate and glutamate as possible ncurotransmitters in the visual cortex. J. Neurosci. 1:427439.

Bloomfield, S. A., and J. E. Dowling (1985) Roles of aspartate and glutamate in synaptic transmission in rabbit retina. I. Outer plexiform layer. J. Neurophysiol. 53: 699-713.

Buchanan, J. T., L. Brodin, N. Dale, and S. Grillner (1987) Reticulospinal neurones activate excitatory amino acid receptors. Brain Res. 408: 321-325.

Butler, A. B., and J. A. Jane (1977) Interlaminar connections of rat visual cortex: An ultrastructural study. J. Comp. Neurol. 174: 521534.

Capowski, J. J., and M. J. Sedivec (1981) Accurate computer reconstruction and graphics display of complex neurons utilizing state-ofthe-art interactive techniques. Comput. Biomed. Res. 14: 518-532.

Chronwall, B., and J. R. Wolff (1980) Prenatal and postnatal development of GABA-accumulating cells in the occipital neocortex of rat. J. Comp. Neurol. 190: 187-208.

Cipolloni, P. B., and A. Peters (1979) The bilaminar and banded distribution of the callosal terminals in the posterior neocortex of the rat. Brain Res. 176: 33-47.

Cline, H. T., E. A. Debski, and M. Constantine-Paton (1987) $\mathrm{N}$-Methyl-D-aspartate receptor antagonist desegregates eye-specific stripes. Proc. Natl. Acad. Sci. USA 84: 4342-4345.

Collingridge, G. L., and T. V. P. Bliss (1987) NMDA receptors-their role in long-term potentiation. Trends Neurosci. 10: 288-293.

Collingridge, G. L., S. J. Kehl, and H. McLennan (1983a) The antagonism of amino acid-induced excitations of rat hippocampal CAl neurones in vitro. J. Physiol. (Lond.) 334: 19-31.

Collingridge, G. L., S. J. Kehl, and H. McLennan (1983b) Excitatory amino acids in synaptic transmission in the Schaffer collateral-commissural pathway of the rat hippocampus. J. Physiol. (Lond.) 334: 33-46.

Cronly-Dillon, J., and G. W. Perry (1979) Effect of visual experience on tubulin synthesis during a critical period of visual cortex development in the hooded rat. J. Physiol. (Lond.) 293: 469-484.

Crunelli, V., S. Forda, and J. S. Kelly (1983) Blockade of amino acidinduced depolarizations and inhibition of excitatory post-synaptic potentials in rat dentate gyrus. J. Physiol. (Lond.) 341: 627-640.

Crunelli, V., J. S. Kelly, N. Leresche, and M. Pirchio (1987) On the excitatory post-synaptic potential evoked by stimulation of the optic 
tract in the rat lateral geniculate nucleus. J. Physiol. (Lond.) 384: 603618 .

Curtis, D. R., and J. C. Watkins (1963) Acidic amino acids with strong excitatory actions on mammalian neurones. J. Physiol. (Lond.) 166: $1-14$.

Cusick, C. G., and R. D. Lund (1981) The distribution of the callosal projection to the occipital visual cortex in rats and mice. Brain Res. 214: 239-259.

Dale, N., and S. Grillner (1986) Dual-component synaptic potentials in the lamprey mediated by excitatory amino acid receptors. J. Neurosci. 6: 2653-2661.

Davies, J. D., and J. C. Watkins (1979) Selective antagonism of amino acid-induced and synaptic excitation in the cat spinal cord. J. Physiol. (Lond.) 297: 621-635.

Davies, J., and J. C. Watkins (1981) Differentiation of kainate and quisqualate receptors in the cat spinal cord by selective antagonism with gamma-D (and L)-glutamylglycine. Brain Res. 206: 172-177.

Davies, J., and J. C. Watkins (1982) Actions of D and L forms of 2-amino-5-phosphonovalerate and 2-amino-4-phosphonobutyrate in the cat spinal cord. Brain Res. 235: 378-386.

Davies, J., R. H. Evans, A. W. Jones, D. A. Smith, and J. C. Watkins (1982) Differential activation and blockade of excitatory amino acid receptors in the mammalian and amphibian central nervous systems. Comp. Biochem. Physiol. 72C: 211-224.

Davies, J., A. J. Miller, and M. J. Sheardown (1986) Amino acid receptor mediated excitatory synaptic transmission in the cat red nucleus. J. Physiol. (Lond.) 376: 13-29.

Dingledine, R., M. A. Hynes, and G. L. King (1986) Involvement of $\mathrm{N}$-methyl-D-aspartate receptors in epileptiform bursting in the rat hippocampal slice. J. Physiol. (Lond.) 380: 175-189.

Donoghue, J. P., R. J. Wenthold, and R. A. Altschuler (1985) Localization of glutaminase-like and aspartate aminotransferase-like immunoreactivity in neurons of cerebral neocortex. J. Neurosci. 5: 25972608.

Eckenstein, F. P., R. W. Baughman, and J. Quinn (1987) An anatomical study of cholinergic innervation in rat cerebral cortex. Neuroscience 25: $457-474$.

Elberger, A. J., and G. A. Looney (1985) Visual cortical pathways via the corpus callosum with possible excitatory neurotransmitters in the rat. Soc. Neurosci. Abstr. 11:650.

Evans, R. H., S. J. Evans, P. C. Pook, and D. C. Sunter (1987) A comparison of excitatory amino acid antagonists acting at primary afferent $\mathrm{C}$ fibres and motoneurones of the isolated spinal cord of the rat. Br. J. Pharmacol. 91: 531-537.

Flatman, J. A., P. C. Schwindt, and W. E. Crill (1986) The induction and modification of voltage-sensitive responses in cat neocortical neurons by N-methyl-D-aspartate. Brain Res. 363: 62-77.

Forsythe, I. D., and G. L. Westbrook (1988) Slow excitatory postsynaptic currents mediated by $\mathrm{N}$-methyl-D-aspartate receptors on cultured mouse central neurones. J. Physiol. (Lond.) 396: 515-533.

Frazier, D. T., T. Narahashi, and M. Yamada (1970) The site of action and active form of local anesthetics. Experiments with quaternary compounds. J. Pharmacol. Exp. Ther. 171: 45-51.

Ganong, A. H., T. H. Lanthorn, and C. W. Cotman (1983) Kynurenic acid inhibits synaptic and acidic amino acid-induced responses in the rat hippocampus and spinal cord. Brain Res. 273: 170-174.

Hablitz, J. J., and I. A. Langmoen (1986) N-methyl-D-aspartate receptor antagonists reduce synaptic excitation in the hippocampus. J. Neurosci. 6: 102-106.

Hallman, L. E., B. R. Schofield, and C.-S. Lin (1988) Dendritic morphology and axon collaterals of corticotectal, corticopontine, and callosal neurons in layer $\mathrm{V}$ of primary visual cortex of the hooded rat. J. Comp. Neurol. 272: 149-160.

Hayashi, T. (1954) Effects of sodium glutamate on the nervous system. Keio J. Med. 3: 183-192.

Herron, C. E., R. A. Lester, E. J. Coan, and G. L. Collingridge (1985) Intracellular demonstration of an N-methyl-D-aspartate receptor mediated component of synaptic transmission in the rat hippocampus. Neurosci. Lett. 60: 19-23.

Houser, C. R., G. D. Crawford, P. M. Salvaterra, and J. E. Vaughn (1985) Immunocytochemical localization of choline acetyltransferase in rat cerebral cortex: A study of cholinergic neurons and synapses. J. Comp. Neurol. 234: 17-34.

Huettner, J. E., and R. W. Baughman (1986) Primary culture of iden- tified neurons from the visual cortex of postnatal rats. J. Neurosci. 6: 3044-3060.

Huettner, J. E., and R. W. Baughman (1988) The pharmacology of excitatory synapses formed by identified corticocollicular neurons in primary cultures of rat visual cortex. J. Neurosci. 8: 160-175.

Jahr, C. E., and T. M. Jessell (1985) Synaptic transmission between dorsal root ganglion and dorsal horn neurons in culture: Antagonism of monosynaptic excitatory postsynaptic potentials and glutamate excitation by kynurenate. J. Neurosci. 5: 2281-2289.

Jahr, C. E., and K. Yoshioka (1986) Ia afferent excitation of motoneurons in the in vitro newborn spinal cord is selectively antagonized by kynurenate. J. Physiol. (Lond.) 370: 515-530.

Johnson, J. W., and P. Ascher (1987) Glycine potentiates the NMDA response in cultured mouse brain neurons. Nature 325: 529-531.

Juraska, J. M. (1982) The development of pyramidal neurons after eye opening in the visual cortex of hooded rats: A quantitative study. J. Comp. Neurol. 212: 208-213.

Karlsen, R. L., and F. Fonnum (1978) Evidence for glutamate as a neurotransmitter in the corticofugal fibres to the dorsal lateral geniculate body and the superior colliculus in rats. Brain Res. 151:457467.

Kleinschmidt, A., M. F. Bear, and W. Singer (1987) Blockade of "NMDA" receptors disrupts experience-dependent plasticity of kitten striate cortex. Science 238: 355-358.

Krnjevic, K. and J. W. Phillis (1963) Iontophoretic studies of neurones in the mammalian cerebral cortex. J. Physiol. (Lond.) 165: 274-304.

Lynch, G. and M. Baudry (1984) The biochemistry of memory: A new and specific hypothesis. Science 224: 1057-1063.

MacDermott, A. B., and N. Dale (1987) Receptors, ion channels and synaptic potentials underlying the integrative actions of excitatory amino acids. Trends Neurosci. 10: 280-284.

MacDermott, A. B., M. L. Mayer, G. L. Westbrook, S. I. Smith, and J. L. Barker (1986) NMDA-receptor activation increases cytoplasmic calcium concentration in cultured spinal cord neurones. Nature 321: 519-522.

Madl, J. E., A. A. Larson, and A. J. Beitz (1986) Monoclonal antibody specific for carbodiimide-fixed glutamate: Immunocytochemical localization in rat CNS. J. Histochem. Cytochem. 34: 217-226.

Madl, J. E., A. J. Beitz, R. L. Johnson, and A. A. Larson (1987) Monoclonal antibodies specific for fixative-modified aspartate: Immunocytochemical localization in the rat CNS. J. Neurosci. 7: 26392650.

Matute, C., and P. Streit (1985) Selective retrograde labelling with $\left[{ }^{3} \mathrm{H}\right]$-D-aspartate in afferents to the mammalian superior colliculus. J. Comp. Neurol. 241: 34-49.

Mayer, M. L., and G. L. Westbrook (1985) The action of N-methylD-aspartic acid on mouse spinal neurones in culture. J. Physiol. (Lond.) 361: 65-90.

Mayer, M. L., and G. L. Westbrook (1987) The physiology of excitatory amino acids in the vertebrate central nervous system. Prog. Neurobiol. 28: 197-276.

Mayer, M. L., V. Crunelli, and J. A. Kemp (1984) Lithium ions increase action potential duration of mammalian neurons. Brain Res. 293: 173-177.

McCormick, D. A., B. W. Connors, J. W. Lighthall, and D. A. Prince (1985) Comparative electrophysiology of pyramidal and sparsely spiny stellate neurons of the neocortex. J. Neurophysiol. 54: 782806.

McDonald, J. K., J. G. Parnavelas, A. N. Karamanlidis, and N. Brecha (1982a) The morphology and distribution of peptide-containing neurons in the adult and developing visual cortex of the rat. II. Vasoactive intestinal polypeptide. J. Neurocytol. 11: 825-837.

McDonald, J. K., J. G. Parnavelas, A. N. Karamanlidis, N. Brecha, and J. I. Koenig (1982b) The morphology and distribution of peptidecontaining neurons in the adult and developing visual cortex of the rat. I. Somatostatin. J. Neurocytol. 11: 809-824.

McLennan, H., and D. Lodge (1979) The antagonism of amino acidinduced excitation of spinal neurones in the cat. Brain Res. 169: 8390.

Miller, M. W., and B. A. Vogt (1984) Heterotopic and homotopic callosal connections in rat visual cortex. Brain Res. 297: 75-89.

Miller, R. F., and M. M. Slaughter (1986) Excitatory amino acid receptors of the retina: Diversity of subtypes and conductance mechanisms. Trends Neurosci. 9: 211-218. 
Nelson, P. G., R. Y. K. Pun, and G. L. Westbrook (1986) Synaptic excitation in cultures of mouse spinal cord neurones: Receptor pharmacology and behaviour of synaptic currents. J. Physiol. (Lond.) 372: $169-190$.

Nowak, L., P. Bregestovski, P. Ascher, A. Herbet, and A. Prochiantz (1984) Magnesium gates glutamate-activated channels in mouse central neurones. Nature 307: 462-465.

O'Brien, R. J., and G. D. Fischbach (1986a) Characterization of excitatory amino acid receptors expressed by embryonic chick motoneurons in vitro. J. Neurosci. 6: 3275-3283.

O'Brien, R. J., and G. D. Fischbach (1986b) Excitatory synaptic transmission between interneurons and motoneurons in chick spinal cord cell cultures. J. Neurosci. 6: 3284-3289.

Olavarria, J., and R. C. Van Sluyters (1983) Widespread callosal connections in infragranular visual cortex of the rat. Brain Res. 279: 233237.

Olavarria, J., and R. C. Van Sluyters (1985) Organization and postnatal development of callosal connections in the visual cortex of rat. J. Comp. Neurol. 239: 1-26.

Olney, J. W., M. T. Prince, T. A. Fuller, J. Labruyere, and L. Samson (1986) The antiexcitotoxic effects of certain anesthetics, analgesics and sedative-hypnotics. Neurosci. Lett. 68: 29-34.

Parnavelas, J. G., A. R. Lieberman, and K. E. Webster (1977) Organization of neurons in the visual cortex, area 17, of the rat. J. Anat. 124: 305-322.

Parnavelas, J. G., R. A. Burne, and C.-S. Lin (1983) Distribution and morphology of functionally identified neurons in the visual cortex of the rat. Brain Res. 261: 21-29.

Perkins, M. N., and T. W. Stone (1982) An iontophoretic investigation of the actions of convulsant kynurcnincs and thcir interaction with the endogenous excitant quinolinic acid. Brain Res. 247: 184-187.

Peters, A., C. C. Proskauer, M. L. Feldman, and L. Kimerer (1979) The projection of the lateral geniculate nucleus to area 17 of the rat cerebral cortex. V. Degenerating axon terminals synapsing with Golgi impregnated neurons. J. Neurocytol. 8: 331-357.

Ribak, C. E., R. M. Bradburne, and A. B. Harris (1982) A preferential loss of GABAergic, symmetric synapses in epileptic foci: A quantitative ultrastructural analysis of monkey neocortex. J. Neurosci. 2: 1725-1735.

Rothman, S. M., and M. Samaie (1985) Physiology of excitatory synaptic transmission in cultures of dissociated rat hippocampus. J. Neurophysiol. 54: 701-713.

Schliebs, R., E. Kullmann, and V. Bigl (1986) Development of glu- tamate binding sites in the visual structures of the rat brain. Effect of visual pattern deprivation. Biomcd. Biochim. Acta 45: 495-506.

Schofield, R. B., L. E. Hallman, and C.-S. Lin (1987) Morphology of cortical cells in the primary visual cortex of hooded rats. J. Comp. Neurol. 261: 85-97.

Sloviter, R. S. (1987) Decreased hippocampal inhibition and a selective loss of interneurons in experimental epilepsy. Science 235: 7376.

Strichartz, G. R. (1973) Inhibition of sodium currents in myelinated nerve by quaternary derivatives of lidocaine. J. Gen. Physiol. 62: 3757.

Stewart, W. W. (1978) Functional connections between cells as revealed by dye-coupling with a highly fluorescent naphthalimide tracer. Cell 14: 741-759.

Thomson, A. M. (1986) A magnesium-sensitive post-synaptic potential in rat cerebral cortcx rescmbles ncuronal responses to $\mathrm{N}$-methylaspartate. J. Physiol. (Lond.) 370: 531-549.

Thomson, A. M., D. C. West, and D. Lodge (1985) An N-methylaspartate receptor-mediated synapse in rat cerebral cortex: A sight of action of ketamine? Nature 313: 479-481.

Tsumoto, T., H. Masui, and H. Sato (1986) Excitatory amino acid transmitters in neuronal circuits of the cat visual cortex. J. Neurophysiol. 55: 469-483.

Tsumoto, T., K. Hagihara, H. Sato, and Y. Hata (1987) NMDA receptors in the visual cortex of young kittens are more effective than those of adult cats. Nature 327: 513-514.

Walk, D., and C. P. Walters (1973) Effect of visual deprivation on depth discrimination of hooded rats. J. Comp. Physiol. Psychol. 85 : $559-563$.

Watkins, J. C., and R. H. Evans (1981) Excitatory amino acid transmitters. Annu. Rev. Pharmacol. Toxicol. 21: 165-204.

Wiesel, T. N., and D. H. Hubel (1963) Single-cell responses in striate cortex of kittens deprived of vision in one eye. J. Neurophysiol. 26: 1003-1017.

Wigstrom, H., B. Gustafsson, and Y.-Y. Huang (1986) Mode of action of excitatory amino acid receptor antagonists on hippocampal longlasting potentiation. Neuroscience 17: 1105-1115.

Wree, A., G. Kulig, P. Gutmann, and K. Zilles (1985) Modification of callosal afferents of the primary visual cortex ipsilateral to the remaining eye in rats monocularly enucleated at different stages of ontogeny. Cell Tissue Res. 242: 433-436.

Zilles, K. (1985) The Cortex of the Rat, Springer-Verlag, Berlin. 